\title{
建築基準法の構造計算規定及びその荷重組合せと 長期・短期概念の成立過程
}

\author{
THE PROCESS OF THE FORMATION OF THE STRUCTURAL CALCULATION \\ CODE OF THE BUILDING STANDARD LAW, IT'S LOADS COMBINATION \\ AND SUSTAINED-AND-TEMPORARY-CONCEPT
}

\author{
大橋 雄二* \\ Yuji OHASHI
}

\begin{abstract}
This paper reports the process of the formation of the structural calculation code of the Building Standard Law, which was enacted in 1950, it's loads combination and "sustained" -and"temporary"-concept.

After the Great Kanto Earthquake of 1923, earthquake load was coded in the Urban Building Law in 1924. After the Muroto Typhoon of 1934, a lot of reseaches for temporary loads were taken. "Sustained"-and-"temporary"-concept of loads combination was adopted in the War-TimeStandards in 1944.

"Sustained"-and- "temporary"-concept was adopted for both loads combination and allowable stresses in the Building Standard Law.

Keywords : building regulations, building code, structural calculation, allowable stress, load, loads combination

建築法規, ·建築基準, 構造計算, 許容応力度, 荷重, 荷重組合せ
\end{abstract}

\section{1.はじめに}

建築基準法（以下「基準法」と略す。）は建築物の最 低基準を定め, 安全確保に貢献してきた。一方, 近年, 建築規制の国際調和から規制の見直しの必要性も出てい る。このため, 筆者は建築法令の変遷と背景の調査が必 要と考え，構造強度規定に関する調査を発表”してきた。 構造法規制の既往の研究に市街地建築物法 (以下「物法」 と略す。）に至る法令案の構造強度規定の検討過程に関 するもの $)^{2}$ があるが，本論は，文献調查により，基準法 制定時の構造計算規定およびその長期・短期概念と荷重 組合せの成立過程を示し，問題点等を指摘する。長期・ 短期概念は限界状態の概念とも関係が深く，その調査は 今後の構造計算法の検討の一助となると考える。ただし， 本論は，法規定等の制定の背景と考え方を対象としてお り，規定值の理論的妥当性等には触れていない。

\section{2. 基準法の棧造計算規定等の成立経緯}

2.1. 明治期の建築規制と東京市区改正計画 日本は明治維新から近代化を始めた。首都東京は火災
に弱かったため，政府は家屋不燃化と都市構造の変革を 図り, 明治 21 年 (1888) に「東京市区改正条例」を制 定した ${ }^{33}$ 。内務省の東京市区改正委員会は東京市の建築 条例案を検討し, 諸外国の法令を参考に妻木頼黄らが条 例の草案を作成したが21,4)，実現しなかった。

その草案類中 ${ }^{51}$ に構造計算に触れているものがある が, 構造強度規定は少なく, それも木造と組積造の構造 詳細の規定が大半であった ${ }^{21}$ 。草案類で最後期のものと 見られる明治 27 年 12 月 3 日付「東京市建築条例」案5! には，木造，土蔵造，棟瓦造，石造の規定があるが，防 火，換気，通風等の事項が中心で，構造強度関係は基礎； 棟瓦造・石造の壁厚, 組積法等である。木造は床高等の 衛生, 防湿, 防火規定のみで構造強度規定はない。第 2 章「(建築) 認可及検査」第 12 条に「特別ノ重量 7 支持 スヘキ柱梁ノ仕様書二八其抗力ノ計算习書入ルヘシ」と ある。その他の草案中5!にも同様の規定があるが, 荷重 値の規定はない。ただし，ここで参考された伯林 (ベル リン) 建築条例（1887 年（明治 20）公布)には「建築 材料ノ重量」,「建築諸部ノ自重及加重」「建築材ノ安全 
強度」の規定があり，翻訳資料6)が存在する。

明治 6 年 (1873) に神奈川県は家屋防火, 衛生が中心 の「家作建方条目」7)制定した。明治 19 年 (1886), コレラ等の流行を背景に港を持つ 5 府県は長屋の衛生を 中心の規則を制定した ${ }^{8 / 9)}$ 。明治 30 年 (1897) 年頃まで に多府県が道路, 衛生, 防火関係の建築規則を制定し $た^{9)}$ 。明治期の府県の建築規制は防火と衛生確保が中心 だった。

明治 24 年 (1891) の濃尾地震の翌年には「震災予防 調查会」が設置され，耐震構造の研究が始まった ${ }^{10\}}$ 。

2.2. 建築学会東京市建築条例案亡警視庁建築取締規則 案

明治 30 年頃に鉄骨造と RC 造が導入され ${ }^{10)}$ ，これら

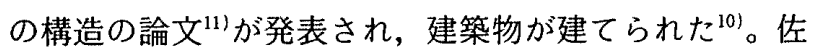
野利器は大正 3 年 (1914) に家屋耐震構造論 ${ }^{12)}$ をまめ, 震度法を示し, 地震に対し建築物の強度, 渆性, 粘勒性 の確保を推奨し, 東京下町の予期震度を 0.3 とした 佐野は風圧力研究 ${ }^{13)}$ も行い, 風速之風圧の関係 $(p=$ $w \cdot v^{2} / g, p$ : 風圧, $w$ : 空気密度, $v$ : 風速, $g:$ 重力 加速度としていた）や各測候所で記録された最大風速值 を示した。

明治 39 年 (1906), 東京市長の依頼から建築学会は東 京市建築条例案（以下「学会条例案」と略す。）の検討 を始めた ${ }^{14)}$ 。東京市建築条例起稿委員会（委員長曾炛達 蔵）を設置し，欧米 17 か国 40 都市の建築条例を収集し 検討した。大正 2 年 (1913) に成案を提出したが, 実現 しなかった。検討の幹事は内田祥三, 構造強度関係は第 三編「材料及結構」, 結構の原案作成者は佐野であった ここで木造, 木骨造, 土蔵造, 棟瓦造, 石造, コンクリー 卜造, 鉄筋コンクリート造, 鉄骨造について規定し, 構 造計算規定として「強弱計算標準」を定め, (1)材料の重 量(2)材料の安全応力強度(3)床の活荷重(4)大梁の活荷重の 低減(5)水平風圧（建築物は $45 \mathrm{lb} . / \mathrm{ft}^{2}$, 独立煙突は 50 lb. $/ \mathrm{ft}^{2}$ ) (6)地盤の許容荷重(7)圧縮材の安全荷重(8)梁材の 安全湾曲率, を規定した ${ }^{15)}$ 。

この検討で参考にした欧米の建築条例中, 詳細な構造 計算規定を持つものにニューヨーク市建築条例 (1899 年

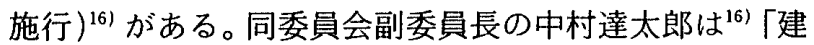
築材料の強さ及び其他の性質に就て建築条例中に規定し あるもの甚稀なり唯千八百九十九年十二月より実施され たる紐克の建築条例中には頗る詳細に規定しあり此点に 於ては欧州諸市の建築条例は遙かに後へに瞠若たりとい ふべきなり」と述べ，内容を紹介した。この条例では， 水平力に風圧力 $30 \mathrm{lb} . / \mathrm{ft}^{2}$ （ブレースでは 5 割増）が規 定されていた2)。家屋耐震構造論で震度法が示されたが, 同時期に佐野らが検討した学会条例案には地震力は規定 されなかった。水平力は風圧力のみが規定された。

明治 42 年（1909）に大阪府 ${ }^{17}$, 明治 45 年 (1912) に
兵庫県は ${ }^{18)}$ ，建築取締規則を制定した。これらの多くは 防火之衛生規定で, 材料規定のほかは，構造強度規定は 少なく,大阪府の規則の木造の規模制限(軒高 35 尺以下, 層数 3 以下), 土台, 基礎, 地階の擁壁の規定 ${ }^{17)}$, 兵庫 県の規則の土台，基礎の規定 ${ }^{18)}$ な゙であった。

学会条例案の後, 警視庁で佐野, 内田, 警視庁技師笠 原敏郎らが学会条例案を元に警視庁建築取締規則案を検 討し ${ }^{191}$ ，大正 7 年 (1918) に最終案 ${ }^{201}$ を作成した。強度 計算規定に地震力はなく, 風圧力は独立煙突で $40 \mathrm{lb}$./

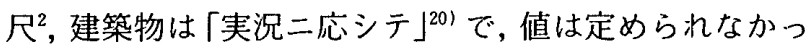
た。 $\mathrm{RC}$ 造の計算式等は学会条例案より詳細でおった

明治末には研究文献等を参考に構造計算をした鉄骨 造, $\mathrm{RC}$ 造建築物が建設され始めた ${ }^{10)}$ 。内藤多仲は大正 11 年 (1922) に架構建築耐震構造論 ${ }^{21}$ を発表し, 水平 力の応力計算法を示したが，この直前に日本興澲銀行の 構造計算で固定荷重, 積載荷重に加え水平震屡 $1 / 15$ の 地震力を採用した。水平力として風圧力 $\left(30 \mathrm{lb} . / \mathrm{ft}^{2}\right)$ も考慮したが，これは22)「震力に比し非常に小なり。さ ればこの場合地震のみを考慮すれば可なり。」した。 一般床の積載荷重は $550 \mathrm{~kg} / \mathrm{m}^{2}$ であった が計算した大阪高島屋と大阪商船本社の水平震度は 1/20(0.05) であった

\section{3. 市街地建築物法の制定}

大正 3 年 (1914) の第一次世界大戦で日本の産業は発 展し, 大都市へ人口と工場が集中し, 東京以外の大都市 でも都市計画と建築法制の整備が必要になった ${ }^{24)}$ 。大正 8 年 (1919), 東京等の 6 大都市を対象に, 都市計画法 と物法が制定され ${ }^{25)}$ ，翌年施行されて近代建築䙺制の出 発点になった。物法第 12 条に「主務大臣八建築物ノ構造, 設備又八敷地二関シ衛生上又八保安上必要ナル規定习設 クルコトヨ得」とされ, 学会条例案と警視庁建築取締䙺 則案が基になり構造強度規定が施行規則 ${ }^{261}$ に定められ た。

構造計算規定では ${ }^{26)}$, 材料重量, 㕅の動荷重, 許容応 力度, 計算式等が定められた。積雪荷重, 風圧力, 地震 力はなく, 長期 - 短期概念もなかった。許容応力度は安 全率 3 程度の值であった。動荷重（積載荷重）は現在よ

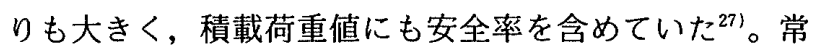
時の鉛直荷重の計算のみが義務付けられたが，施行規則 第 47 条は「地方長官八建築物ノ構造強度二関シ土地ノ 状況二依り本節二定ムルモノノ外必要ナル規定习設クル コトヨ得」とされ, 府県の細則で他の荷重も規定できる としていた。荷重組合せは明示されなかった。

ベルリン建築条例, 二ューヨーク建築条例, 学会条例 案，警視庁建築取締規則案，制定時の物法施行規則にお ける主な荷重および許容応力度を表一1 および表一2に 示す。 


\section{4. 関東大地震と耐震計算の義務付け}

大正 12 年 (1923) の関東大地震の被害から，翌年, 物法施行規則に水平震度 0.1 以上等の耐震規定が定めら れた。改正規定は, ${ }^{28)}(1)$ 木造の柱の小径の強化, 筋違い . 方杖の設置(2)石造のがりょう（鉄又は $\mathrm{RC}$ 造）の設置， 壁厚・壁長の強化(3)鉄骨造の方杖・ブレース・壁の適切 な設置, 帳壁の緊結・ホロタイル等の使用禁止(4) RC 造の主筋継手長は $25 \mathrm{~d}$ 以上，梁鉄筋の複筋化，柱の小 径の強化・鉄筋比は $1 / 80$ 以上(5)高さ 50 尺を超える煙突 は鉄または RC 造にする(6)地震力水平震度 0.1 以上,

表一1 物法以前の建築法令案等における主な荷重の比較

\begin{tabular}{|c|c|c|c|c|c|c|}
\hline \multicolumn{2}{|c|}{ 法令名 } & ベル & ニュ- & 学会東京 & & \\
\hline 固 & $\begin{array}{l}\text { レンカ皘 } \\
\text { 花コウ岩 } \\
\mathrm{RC}\end{array}$ & $\begin{array}{l}1600 \\
2700 \\
2000\end{array}$ & $\begin{array}{c}1840(115) \\
2720(170) \\
-\end{array}$ & $\begin{array}{l}1792(112) \\
2720(170) \\
2400(150)\end{array}$ & $\begin{array}{l}1956(120) \\
2445(150) \\
2282(140)\end{array}$ & $\begin{array}{l}1900 \\
2500 \\
2300\end{array}$ \\
\hline $\begin{array}{l}\text { 積 } \\
\text { 载 }\end{array}$ & $\begin{array}{l}\text { 住家 } \\
\text { 事務所 } \\
\text { 学校 } \\
\text { 集会所 } \\
\text { 軽量倉匭 } \\
\text { 重量倉庫 }\end{array}$ & $\begin{array}{c}* 1 \\
250 \\
- \\
- \\
\overline{* 2} \\
250 \\
850 \\
* 3\end{array}$ & $\begin{array}{l}293(60) \\
732(150) 4 \\
366(75) \\
439(90) \\
585(120) \\
732(150)\end{array}$ & $\begin{array}{l}293(60) \\
488(100) \\
488(100) \\
585(120) \\
732(150) \\
1219(250)\end{array}$ & $\begin{array}{l}247(50) \\
370(75) \\
420(\times 85) \\
494(100) \\
\text { 奉況 } \\
\text { 垁況 }\end{array}$ & $\begin{array}{r}250 \\
370 \\
420 \\
500 \\
\text { 実況 } \\
\text { 実況 }\end{array}$ \\
\hline 風 & $\begin{array}{l}\text { 建筑物 } \\
\text { 煙立煙突 }\end{array}$ & - & 146 ( & $\begin{array}{l}219(45) \\
244(50)\end{array}$ & $\begin{array}{l}\text { 実況 } \\
198(\text { 40) }\end{array}$ & - \\
\hline
\end{tabular}

数値の単位は固定荷重が $\mathrm{kg} / \mathrm{m}^{3}$ 、後の( )内太字 $\mathrm{lb} . / \mathrm{ft}^{3}$

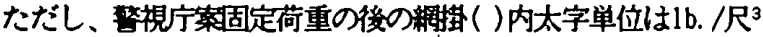
皘載荷重・風压力の単位は $\mathrm{kg} / \mathrm{m}^{2}$ 、後の( )内太字 $1 \mathrm{~b} . / \mathrm{ft}^{2}$ 、

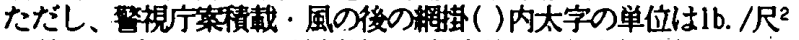
下段の( )内はメートル法以外の元規定值。これを換算した *1 柱·梁の值、固定荷重十棈載荷重の場合 $500 \mathrm{~kg} / \mathrm{m}^{2}$ *2 工場・物冝の値、固定荷重十積載荷重の場合 $750 \mathrm{~kg} / \mathrm{m}^{2}$ *3 毫倉の值 固定荷重+積載荷重の場合

*4 1 陵の值、2階以上では366kg/m² $\left(75 \mathrm{lb} . / \mathrm{ft}^{2}\right)$

*5 フレース用の值は5割增しで $219 \mathrm{~kg} / \mathrm{m}^{2}\left(451 \mathrm{~b} . / \mathrm{ft}^{2}\right)$
などであった。

震度規定導入に際しては, 関東大地震の規模を参考に, 将来の予想地震の水平震度を 0.3 程度とし, 許容応力度 の安全率約 3 が考慮された。北沢五郎は29) 「佐野先生が

(中略) 法規には 0.1 と規定し許容強度をとり,そして 震度 0.3 で計算をして, 破壊強度以内で収まるかどうか を調べろといわれた。(中略) 耐震計算としては, 下町 の震度を 0.3 として, 破壊の一歩手前にあるようにする には, 0.1 で計算して許容強度を採ればよいというお考 えであったかと思う。(中略) しかし少時経過して震災 予防調査会から復興院に対して意見書が出てきた。それ は震度は 0.3 とし強度を破壊強度以内として計算するよ うにということであった。(中略) しかし (中略) 計算の 手数を理由に原案で押しとうした」と記している。

同年，地震力導入に際し建築学会は、構造強度計算規 準」301を制定し，「柱梁等ノ計算二八常時荷重ノ外地震 等二依ル横力 $尹$ 加算ス」「震力八震度 算出ス」「風力八土地ノ状況ニヨリ, 適当ニ之レヨ仮定ス」 「横力トシテ八震力及風力ノ中, 其影響ノ大ナルモノ 採ル」とし, 実用的な水平力の応力計算法として架構形 式に応じた横力分布係数を示した ${ }^{30)}$ 。

\section{5. 許容応力度研究の進歩と $\mathrm{RC}$ 規準の制定}

関東大地震後, コンクリート研究が進んだ。従来, コ ンクリートの調合理論は確立してなく，物法施行規則で も標隼的調合に対し，一律の許容応力度（表一2参照） が定められていた ${ }^{31)}$ 。浜田 稔は年水セメント比説を紹 介し，「同規則の下に作られるコンクリートの品質は極 めて不均一であって此を同一許容強度で用了事は甚だ不 合理である」と指摘し，コンクリートの強度に応じで ${ }^{321}$ 「単に規定としては安全率のみを一定に保つやうにす

表一2 物法以前の建築法令案等における主な許容応力度の比較

\begin{tabular}{|c|c|c|c|c|c|c|c|c|c|c|c|c|}
\hline 法令名 & ベルリン廷 & 建空 & 条例 & $=z-5$ & $\exists-ク 1$ & 建条例 & 学会 & 東京市 & 建婪 & 桝案 & 暂視庁建取粮规則案 & 物法施行规則 \\
\hline 蚛力 & 压引蜶 & 逝 & 曲 $15^{\prime}$ & 区唃 & 引張 & せん断 曲け & 圧唃 & 引張 & せん断 & 于 曲伊 & 压䧿 引張 せん断 曲け & 压 引せ断 曲少 \\
\hline $\begin{array}{l}\text { 松又は } \\
\text { 白松 }\end{array}$ & 60100 & - & - & $\begin{array}{l}56.2 \\
800\end{array}$ & $\begin{array}{l}56.2 \\
800\end{array}$ & $\begin{array}{rr}2.8 & 56.2 \\
40 & 800\end{array}$ & $\begin{array}{l}49.2 \\
700\end{array}$ & $\begin{array}{l}56.2 \\
800\end{array}$ & - & $\begin{array}{r}56.2 \\
800\end{array}$ & $\begin{array}{ccc}64.2 & 64.2-64.2 \\
1300 & 1300\end{array}$ & $\begin{array}{lll}75 & 75 & 7.5\end{array}$ \\
\hline 花岩岩 & $45-$ & - & - & $\begin{array}{l}70.3 \sim 1 \\
1000 \sim 2\end{array}$ & $\begin{array}{l}168.7 \\
2400\end{array}$ & $\begin{array}{r}12.7 \\
180\end{array}$ & $\begin{array}{r}105.5 \\
1500\end{array}$ & - & $\begin{array}{r}-10.5 \\
150\end{array}$ & $\sim 21.1$ & $108.7--14.8$ & 110 \\
\hline $\begin{array}{l}\text { コンク } \\
\text { リート }\end{array}$ & $-\quad-$ & - & - & $\begin{array}{l}16.2 \\
230\end{array}$ & - & $\begin{array}{r}2.1 \\
-\quad 30\end{array}$ & $21.1 \sim$ & $\begin{array}{l}-35.2- \\
500\end{array}$ & - & & $\begin{array}{ccc}42.5 & -4.25 & 4.25 \\
8600\end{array}$ & $\begin{array}{ccc}45 & 4.5 \quad 4.5 \quad 4.5 \\
& 9.0(\mathrm{RC})\end{array}$ \\
\hline 辎 & 875875 & - & - & $\begin{array}{l}1125 \\
16000\end{array}$ & $\begin{array}{r}1125 \\
16000\end{array}$ & $\begin{array}{rr}633 & 1125 \\
9000 & 16000\end{array}$ & $\begin{array}{r}1125 \\
16000\end{array}$ & $\begin{array}{r}1125 \\
16000\end{array}$ & $\begin{array}{r}703 \\
10000\end{array}$ & $\begin{array}{r}1125 \\
16000\end{array}$ & $\begin{array}{rrrr}1125 & 1125 & 703 & 1125 \\
16000 & 16000 & 10000 & 16000\end{array}$ & $\begin{array}{llll}1150 & 1150 \quad 750 & 115\end{array}$ \\
\hline 錬鉄 & 75075060 & 600 & - & $\begin{array}{r}844 \\
12000\end{array}$ & $\begin{array}{r}844 \\
12000\end{array}$ & $\begin{array}{rr}422 & 844 \\
6000 & 12000\end{array}$ & $\begin{array}{r}844 \\
12000\end{array}$ & $\begin{array}{r}844 \\
12000\end{array}$ & $\begin{array}{r}492 \\
7000\end{array}$ & $\begin{array}{r}844 \\
12000\end{array}$ & $\begin{array}{rrrr}844 & 844 & 492 & 844 \\
12000 & 12000 & 7000 & 12000\end{array}$ & $\begin{array}{llll}850 & 850 & 550 & 85\end{array}$ \\
\hline 锖鉄 & 50025020 & 200 & - & $\begin{array}{r}1125 \\
16000\end{array}$ & $\begin{array}{r}211 \\
\mathbf{3 0 0 0}\end{array}$ & $\begin{array}{rr}211 & 211 \\
3000 & 3000\end{array}$ & $\begin{array}{r}844 \\
12000\end{array}$ & $\begin{array}{r}211 \\
3000\end{array}$ & $\begin{array}{r}211 \\
3000\end{array}$ & $\begin{array}{r}211 \\
3000\end{array}$ & $\begin{array}{rrrr}844 & 211 & 211 & 211 \\
12000 & 3000 & 3000 & 3000\end{array}$ & $\begin{array}{llll}850 & 200 & 200 & 20\end{array}$ \\
\hline
\end{tabular}

単位: $\mathrm{kg} / \mathrm{cm}^{2}$ 下段の数値は、各案のもとの単位による規定值、これを $\mathrm{kg} / \mathrm{cm}^{2}$ に換算した。下段の太文字の数値の単位はlb. /inch ${ }^{2}$

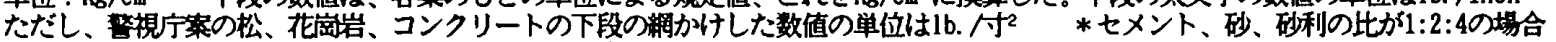


る」こととコンクリートの品質の規定の整備などの改正 が必要であると指摘した。昭和 4 年 (1929), 建築学会 は「コンクリート及鉄筋コンクリート標準仕様書」を定 めた。この頃, 軍艦の建造等から鉄骨造の溶接技術も開 発された ${ }^{33)}$ 。

これらから昭和 5 年 (1930) に建築学会はコンクリー 卜規定を中心に法規改正を建議 ${ }^{34)} し$ ，昭和 7 年 (1932)，

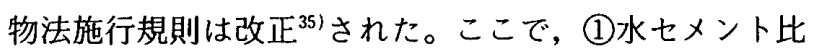
説の導入 $(F=2 K / 20 X, F:$ コンクリート生縮強度, $K: 4$ 週王縮強度， $X:$ 水セメントの重量比）でコンク リートの許容圧縮応力度は $F / 3$ (上限 $70 \mathrm{~kg} / \mathrm{cm}^{2}$ ) (2)軟 鋼の許容応力度が上昇(3)地方長官の許可で鉄骨の溶接が 可能,となった。

建築学会は昭和 8 年 (1933) に「鉄筋コンクリート構 造計算規準」（以下，「RC 規準」と略す。）を発表した。 コンクリートの許容圧縮応力度は $F / 3$ で, 荷重には固 定荷重, 積載荷重, 積雪荷重, 地震力, 風圧 ${ }^{36)}$ を定め, 37)「構造各部は鉛直荷重を受けたる場合, 及び之に地震 力, 風圧の影響を各別に加算せる場合の何れに就きても 安全なる様，その材形及び配筋を設計すべし。」しし， 荷重組合せを示した。(1)積雪荷重は $3 \mathrm{~kg} / \mathrm{m}^{2} / \mathrm{cm}$ (2)水平 震度は 0.1 以上(3)風圧力は $100 \mathrm{~kg} / \mathrm{m}^{2}$ (高さ $15 \mathrm{~m}$ 以下) $150 \mathrm{~kg} / \mathrm{m}^{2}$ (高さ $15 \mathrm{~m}$ 超) 以上, とし ${ }^{36)}$, 横力分布係数 法も示した。

この頃, 府県細則で風圧力が定められ始め, 東京は昭 和 3 年 (1928) に ${ }^{38)}$, 建築物の高さ $6 \mathrm{~m}$ 以下で 75 $\mathrm{kg} / \mathrm{m}^{2}$ 以上, $6 \mathrm{~m}$ 超で $100 \mathrm{~kg} / \mathrm{m}^{2}$ 以上としていた。 $6 大$ 都市の風圧力規定 ${ }^{39)}$ を表一 3 に示す。この時期には風圧 力を速度圧と風力係数の積として定める考え方はなかっ た。

昭和 12 年（1937）5 月, 建築学会は計算法の進歩, 材 料品質の向上, 工法の発達等から外国規定を参考に荷重 と許容応力度の法規改正を建議した ${ }^{40)}$ 。建議に当たり伊

表一3 府県の物法施行細則の風圧力規定 (垂直平面 $1 \mathrm{~m}^{2}$ 当り、これ以上 単位 $\mathrm{kg} / \mathrm{m}^{2}$ )

\begin{tabular}{|c|c|c|c|c|}
\hline $\begin{array}{l}\text { 府県名 } \\
\text { 条文番号 }\end{array}$ & \multicolumn{2}{|c|}{ 建筑物の高 } & $\begin{array}{l}\text { 煙突 } \\
\text { 等*1 }\end{array}$ & 独立 \\
\hline 東京 第27条 & 75 & 100 & 150 & - \\
\hline 神奈川第13条 & 100 & 120 & 200 & - \\
\hline 大阪 第21条 & \multicolumn{2}{|c|}{100} & \multicolumn{2}{|c|}{$200 * 2$} \\
\hline 愛知 第22条 & \multirow{2}{*}{\multicolumn{2}{|c|}{100}} & - & \\
\hline $\begin{array}{l}\text { 京都 第21条 } \\
\text { 兵庫 第31条 }\end{array}$ & & & $\overline{-}$ & 200 \\
\hline
\end{tabular}

*1 高さ $15 \mathrm{~m}$ を超える煙突、物見塔、 広告塔、無線電信用電柱

*2 高さ $15 \mathrm{~m}$ 以下のものにも適用する
藤憲太郎らは ${ }^{41}$ 積載荷重を検討し, ${ }^{271}$ 「強度計算方法の 進歩, 各種建築材料の品質の向上, 或は工法技術の発達 目覚ましく, 此の結果建築物の構造強度上の正確性は, 積載荷重の規定に従来のやうな安全率を考慮す百必要が なくなった (中略) 先づ第一に低減の方針で進む（中略） 第二には規定の用途の種類の増加」と述へ，外国諸都市 の積載荷重值を比較し, 積載荷重算出式を示した。従来 の積載荷重值中の安全率を減らした。武藤清は1934 年のドイッ規格（DIN 1050）改正で鋼材に常時・非常 時の 2 種の許容応力度と応力組合せが定められ非常時許 容応力度は日本上り大きく， ${ }^{421,431} \Gamma$ 独逸に於け吕規格は 1934 年の改正に依つて，各国に例を見ざる新形式とな つた。即ち応力の組合せの方法に依り 2 種類に分ち 第 1 種 常時作用すると考へらるる心力組合 鉛直荷重, 交通荷重及雪荷重に依る応力の組合に依る最大設計応力 第 2 種 非常時的組合応力 常時組合応力に更に, 風何 重, 温度変化等に依る応力を組合せたる最大設計応力」 と紹介した。森 徹は木材の許容応力度における安全率 の考え方を整理し, 欠点補正のうえ, 強度に対し安全率 $3^{44)}$ とした。

これから物法施行規則が改正された ${ }^{45 !}$ 。改正内容は, (1)積載荷重の用途の細分化, 数值の低減(2)木材樹種区分 の細分化, 許容応力度の上昇(3)鋼材許容応力度の上昇(降 伏に対し安全率 1.5 を考慮した。規格材で降伏安全率 1.5 とすると許容引張応力度は $1600 \mathrm{~kg} / \mathrm{cm}^{2}$ となるが, 市場材品質を考虑し $1400 \mathrm{~kg} / \mathrm{cm}^{2} と し た{ }^{42), 431}$ ), である。 改正の背景に時局逼迫による鋼材欠乏, 繊維工業発展に よる木材欠乏もあった ${ }^{44)}$ 。この建議で積雪荷重 (3 $\mathrm{kg} / \mathrm{m}^{2} / \mathrm{cm}$ ) と風圧力 (高さ $15 \mathrm{~m}$ 以下の場合, 速度王 $100 \mathrm{~kg} / \mathrm{m}^{2}$ 等) 案も示し ${ }^{401}$, 風王力は速度圧と風力係数 の積とする考えを示したが, 物法施行規則はこれらは採 用しなかった。

\section{6. 室戸台風被害による従来の構造計算法の反省}

昭和 9 年 (1934) の室戸台風による木造小学校等の被 害から建築学会は風圧力研究を進め, 昭和 13 年 (1933) に木造小学校標準設計案を作成 ${ }^{46)} し$, この構造計算(例で, 固定, 積載, 積雪, 風, 地震の荷重組合せを考慮した ${ }^{46)}$ 。

昭和 11 年 (1936), 棚橋 諒と宇津木 潔 ${ }^{47)}$ は, 建榮 物には多種の荷重が作用するが, 破壊は一つの荷重の増 大のためで, 大きな材料安全率と小さな荷重の構造計算 は部材により終局安全率が異なるとし，.「『酎震安全率』 が現在の計算を似てしては梁と柱に於て異り, 又柱と柱 梁と梁の間に於ても垂直荷重による応力と地震力による 応力との比によつて大に異ることを注意しなければなら ない」我国に於ては積載荷重安全率と, 耐震安全率の 二つに分つて考慮すべき」と指摘した。昭和 13 年(1938), 武藤は耐風設計面から ${ }^{48)}$ 常時荷重之非常時荷重の区別之 割増し係数を用いた非常時荷重組合せを示した。構造安 
全確保に際し, 常時と非常時の区分の概念が導入され, 各構造部材の終局安全率を均等化する方法が検討され始 めた。

武藤らは紀元 2600 年記念日本万国博覧会の木造建築 物の計算規準 ${ }^{49}$ を提案し，(1)非常時荷重は起こり得る極 大値(2)許容応力度は材料強度(3)長期荷重による材料強度 低下の対策として常時荷重は 2 倍する(4)荷重組合せは 「設計用応力は常時荷重と非常時荷重の一との組合せを 比較して定める」(5)地震力は, 博覧会の短期間のため水 平震度 0.2 。永久的建築物では 0.3 程度としたい(6)風圧 力の速度圧は $v^{2} / 16$ で得られ, 高さ $15 \mathrm{~m}$ 以下では 150 $\mathrm{kg} / \mathrm{m}^{2}$ 等, 恒久的構造物ではこれを 250 としたい(49), と した。

昭和 9 年 (1934), 日本学術振興会は建築耐震研究を 始め, 昭和 16 年 (1941) には「建築物耐震構造要項」 を発表した。物法の計算法は構造各部の耐震安全度が一 定しないと指摘し，(1)耐震計算法は終局強度法で，水平 震度は $0.3 \sim 0.4$, 上下震度は $0.15 \sim 0.2$ (2)許容応力度 は終局強度又は降伏点(3)クリープ考慮のため, a. 常時 荷重および地震力による応力, b. 常時荷重を $2 \sim 3$ 倍し た時の応力，のうち大きなものを設計応力とする， ${ }^{501}$ した。

昭和 16 年 (1941) 建築学会は「鉄骨構造計算規準案 $\rfloor^{51)}$ （以下「S 規準」と略す。）を発表し(1)「構造物は常時 のみならず，風圧力・地震力等の作用する場合にありて も充分安全なる様, 各種荷重の合理的組合せを考慮しそ の設計応力を定め各部構造を検すべし」(2) a. 常時荷重, b. 常時荷重および雪荷重, c. 常時荷重および風圧力, d. 常時荷重および地震力, の組合せを考虑し「積雪期 長き地方にありては雪荷重と風圧力又は地震力を同時に 考慮すべし」(3)地震力は水平震度が 0.1 以上(4)風圧力の 速度圧は建築物の高さ $15 \mathrm{~m}$ 以下では $100 \mathrm{~kg} / \mathrm{m}^{2}$ 等（鉄 塔は建築物の 2 倍の值）とし「浮力検定に当りては風圧 力を 2 倍」とした ${ }^{51 !}$ 。武藤は52)「建築物に対する速度圧 に比して鉄塔の類は之を 2 倍に取る事になつて居りま す。(中略) 風で倒れる場合を考えますと, 常時の荷重 はその儘で，風圧力だけが強くなって潰されるのであり ます。普通の建築に付て見ますと, 風で潰される場合に は，普段持つて居ります荷重に対する安全率の余裕があ ります (中略) 然るに鉄塔の類になりますと，その断面 が殆ど風荷重だけで決つてしまふことになりますから， 風に対する安全率は概ね材料の安全率だけ，例へば鋼材 で 1.5 の安全率だけしかない（中略）。建築物に較べま すと, 非常に安全度が不足致しますので，それ等の点を 是正するために荷重を大きくした (中略)。否大きくし たと申しますよりは鉄塔類には普通に取り，建物は特に 軽減したと申す方が適当」と記した。竹山謙三郎は531「風 圧力は通常 $200 \mathrm{~kg} / \mathrm{m}^{2}$ 程度の速度圧を対象として考へて
居るが, 計算に当つては速度圧として其の $1 / 2$ 即 100 $\mathrm{kg} / \mathrm{m}^{2}$ を採つて居り，之の危険率は材料の安全率により 処理される」と記した。

\section{7. 戦争による物法の停止と戦時規格の制定}

物法は戦時措置で昭和 18 年 (1943) に大半が停止し $た^{54}$ 。内内閣技術院科学技術審議会に，資材節約から安全 率低下を目指す戦時規格の策定が諮問された。構造設計 法が見直されたが，材料節約から安全を犠性にするので はなく, 室戸台風以来指摘された計算法の不合理点を改 善した。武藤, 竹山らが中心に, 昭和 19 年 (1944), 臨 時日本標準規格第 532 号「建築物ノ荷重」同第 533 号「建 築物強度計算ノ基本 ${ }^{551}$ （以下「戦時規格」と略す。）が 作られた。

戦時規格は従来より荷重を大きく材料安全率を小さく しており，物法施行規則と比へ，次の特徴を持っていた。 (1)重要な建築物は荷重を適当に増大するとした(2)積載荷 重は物法令より低減された(3)積雪荷重は $2 \mathrm{~kg} / \mathrm{m}^{2} / \mathrm{cm}$ (4) 風圧力は $p=c \cdot q \quad q=40 \sqrt{h}(q:$ 速度圧, $h:$ 高さ $)$ (5)地震力は水平震度が 0.15 (通常地盤), 0.2 (軟弱地盤) (6)応力の組合せは長期・短期の二本立てとした(7)許容応 力度には長期・短期の別はなく，值は物法令の約二倍に なった(8)基礎, 木造, $\mathrm{RC}$ 造は常時と積雪時応力を二倍 するとした(7)計算誤差, 施工誤差, 材料の変動を考慮し て必要に応じ断面を增加するとした，なよ゙である。

石黒によれば56), 戦時規格の検討で, 武藤は(1)荷重は 常時と非常時に分けて予想最大とし, 水平震度は 0.3 , 風圧力の速度圧は $S$ 規集の 2 倍(2)許容応力度は材料の 静的強度に近い值(3)木材, コンクリート等では長期荷重 も考慮し，割增係数 $\alpha$ を 1.5 とした荷重組合せ，を提 案した。荷重組合せに「常時」「非常時」の概念を明示 した。

武藤案は弾性理論では計算が不可能なため, 戦時規格 は弾性理論で可能なように許容応力度はほぼ比例限度ま たは降伏点, 荷重は比較的しばしば繰り返されるものと した ${ }^{53)}$ 。竹山は ${ }^{53)}$ 「構造物の倒壊即ち終極破壊を目標之 して設計するならば予想し得る最大の荷重值, 若くはそ れ以上を対象とするのが理想であらう」「構造物の破壊 強さと云ふものは其の安全性を判定する明確な因子であ るが（中略）応力・断面の計算等之が正確なる解法は尚 大部分今後の研究に俟たねばならない。(中略) 構造物 の弾性強さなるものを考へ, 強度計算は一応此の弾性強 さを目標として行ひ（中略）強度計算にも従来慣用の計 算法を大体そのまま適用することが出来る。(中略) 対 象亡すべき荷重の大いさは（中略）比較的頻度の多い大 いさのものを対象とすべき」と述べた。戦時規格の荷重 は予想最大のものより小さかったが，目標は，より大き な荷重への安全確保であった。許容応力度には長期・短 期はなかったが，态力組合せにクリープ考慮の長期，非 
常時安全確保の短期という概念を採用した。

\section{8. 日本建築規格 建築 3001 の制定}

戦時規格をもとに建築学会構造標準委員会が検討 ${ }^{57}$ し て昭和 22 年 (1947), 日本建築規格建築 3001 「建築物 の構造計算」(JES 3001) ${ }^{581}$ が制定された。これは戦時 規格と比へ，次の主な相違点がある。(1)応力組合せと許 容応力度の両者に長期・短期が採用され, クリープ考慮 の応力割増はなくなった。許容応力度は, 短期が戦時規 格程度で物法の約 2 倍, コンクリートは強度の $2 / 3$, 鋼 材は降伏点。長期は物法の值程度。長期と短期の比は, 木材・コンクリートが $1: 2$, 鉄材が $1: 1.5$ (2)風生力の 速度王は $q=60 \sqrt{h}$ (3)地震力は通常の構造物で水平震度 が 0.2 以上, 軟弱地盤上の木造建築物で 0.3 以上（高層 建築物の上階・屋上突出物は適宜割增す $)^{58)}$, とした。

戦時規格の許容応力度は JES 3001 の短期相当のもの で基礎, 木材, コンクリートはクリープ考慮から長期応 力を 2 倍するとしたが, JES 3001 では鋼材も含め長期 許容応力度が定められた。石黒は56)，建築学会の鉄骨分 科会の検討で，戦時規格に鋼材に長期荷重への安全余裕 が無いとの意見があり，鋼材の長期許容応力度を短期の $2 / 3$ とした，と述べている。ここで「長期・短期」では なく「常時・非常時」の用語の採用も検討したが，「非 常時」は戦争に結びつくため採用しなかった。戦時規格 の常時はクリープを考慮した常時応力の割増しとの概念 が明確だったが，JES 3001 の長期にはそれが貫かれな かった。

竹山は長期についで ${ }^{59)}$ 「木造で問題となるのはクリー プ破壊ではなく，常時に起るクリープ変形である」「木 造の場合では，クリープ変形障害を起させないために長 期応力計算をして居る」と記し，JES の規定について ${ }^{591}$ 「改訂の主要点は, 臨時規格が短期許容応力度 1 本であ つたのに対して, 新に長期許容応力度が追加されたこと で, 構造計算は長期・短期の 2 本建となつたのである。 改訂の理由は一口でいえば, 常時作用して居る荷重に対 しては国際的の許容応力度値を用いて常識的な断面寸法 を確保し度いという気持ちによる (中略) 真意について は規格立案関係者によつてそれぞれの見解があると思う が，少く共木造のクリープ障害防止ということがその理 由の根拠として大きく採り上げられたことは事実であ る。(中略) 鉄筋コンクリート造に対してはクリープの 影響の他，更に未だ明確に掴まれて居ない種々の原因に よつて思わぬ障害を生じないために, 従来の経験によつ てさして不都合を感じて居なかった常識的断面が得られ るように，長期応力計算を採用したものと解釈される。 鉄骨造に対しては長期応力計算の明確な根拠が更につけ 悪くなる。当初は鋼材のクリープ限度から考えて，長期 応力計算の必要がないという意㒻もあつたが，矢張り振 動・腐触, 或は鉄骨造は比較的静定に近い構造が多いの
で計算誤差の影響が大きいこと等から, 不測の障害に備 えて, 旧来の許容応力度 1400 を多少上昇して, 2400/ 1.5 に当る $1600 \mathrm{~kg} / \mathrm{cm}^{2}$ に当るという長期許容応力度が 採用されたといつて良いであろう」「積載荷重值は通常 起こり得る最大值という主旨で定められた臨時摆格当時 の值がそのまま新規格にもひきつがれた。尚新規格の立 案に当つては，積載荷重も常時之臨時に分けたらどうか という案もあったが，安全のためと計算操作を成る可く 簡易化するために, 積載荷重は全部常時荷重として扱う ことになつた」「風圧力としては新規格では我国を襲つ た過去の最大值という意味で $60 \sqrt{h}$ を採ることとなり， 通常起り得る最大值 $40 \sqrt{h}$ を割增した。地震力に対し ては臨時規格と大差なく 0.2 という基準震度が用いられ ている。この值は許容応力度の上昇とにらみ合せ余り従 来と大差のない断面が得られるというねらいから古く慣 用の 0.1 という震度を 2 倍にしただけのことであつて， どの程度の地震を対象として居るかという明確な根拠は ない」と記した。谷口忠は地震力は水平震度 0.3 を提 案していた ${ }^{56\}}$ 。

戦後, 物法が復活し, JES 3001 は計算の特侧とされ, 従来の計算方法と併記された。

\section{9. 建築基準法の制定}

昭和 25 年 (1950), 基準法が制定され物法は廃止 ${ }^{601} さ$

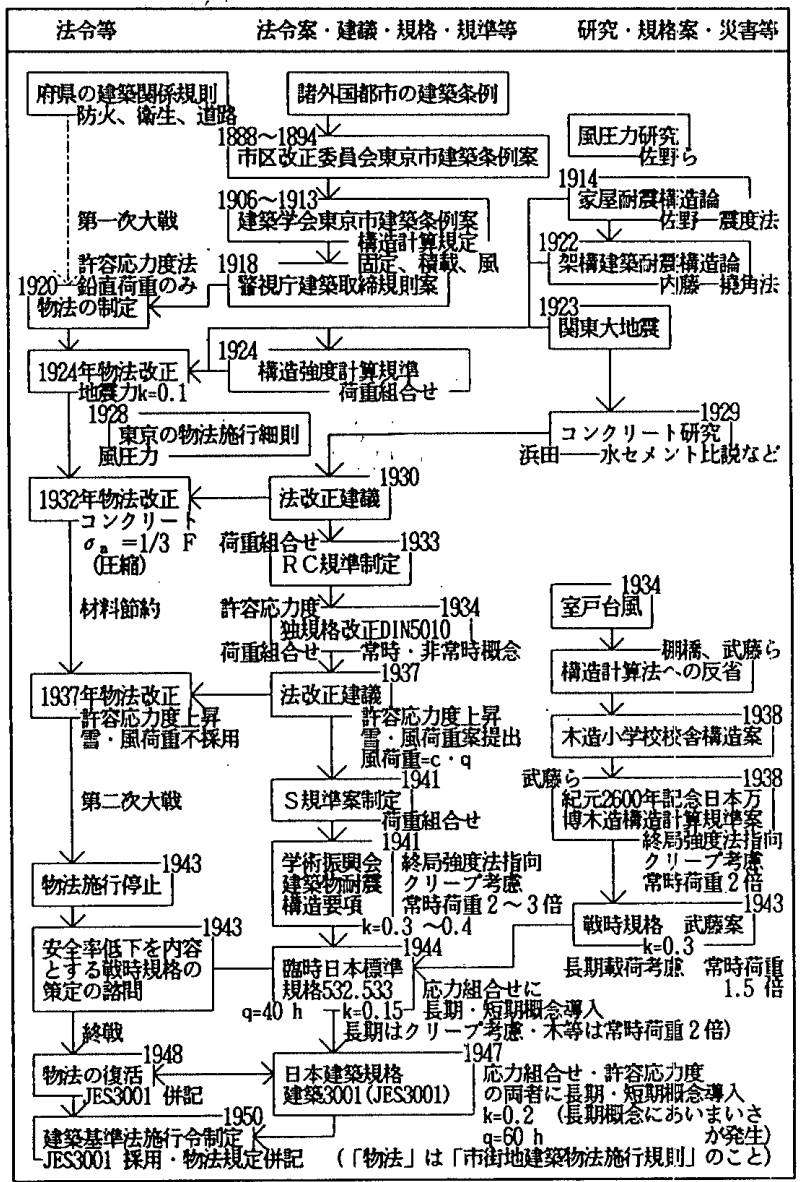

図一1 建築基準法施行令の構造計算規定の成立過程 $(k:$ 水平 震度, $q$ : 速度圧, $c$ : 風力係数) 
れた。構造強度は建築学会が原案を作成し ${ }^{61}$ 施行令に定 められた。基準法の規定の多くは物法から引継がれた。 計算規定に JES 3001 が採用され，(1)計算誤差等による 断面の増大と建築物の重要度による荷重の増大規定等の 削除(2)地震力の高さ方向の分布の定量化, 等の修正がさ れた。これは，基準法は最低基準を定めることおよび規 定事項を明確化する ${ }^{611}$, との方針のためであった。物法 の計算規定は, 特例として昭和 34 年 (1959) まで残った。
図一1に物法から基準法に至る構造計算規定の変遷の 過程を示し, 法令, 基準案等の積雪荷重, 風圧力, 地震 力等を表一 4 に, 荷重 (応力) の組合せを表一 5 に示す。

\section{3. 考 察}

物法制定以前にも少数の建築物では構造計算が行われ た。地震力は風圧力より大きかったので, 荷重は, 固定 荷重, 積載荷重と地震力を組み合わせてていた。制定時の

表一4 各法令, 基準案, 規格等における積載荷重, 積雪荷重, 風俚力, 地震力, 許容応力度等

\begin{tabular}{|c|c|c|c|c|c|c|c|c|c|c|c|c|c|c|c|c|c|c|c|c|}
\hline \multicolumn{3}{|c|}{$\begin{array}{l}\text { 法令等の制定、 } \\
\text { 改正等 }\end{array}$} & $\begin{array}{l}\text { 学会 } \\
\text { 東京 } \\
\text { 市条 } \\
\text { 晒结 }\end{array}$ & 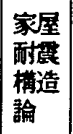 & $\begin{array}{l}\text { 等視 } \\
\text { 庁规 } \\
\text { 則案 }\end{array}$ & $\begin{array}{l}\text { 大9 } \\
\text { 物法 } \\
\text { 施行 } \\
\text { 规則 }\end{array}$ & $\begin{array}{l}\text { 日本 } \\
\text { 興業 } \\
\text { 銀行 } \\
* 4\end{array}$ & $\begin{array}{l}\text { 物法 } \\
\text { 大13 } \\
\text { 改正 }\end{array}$ & 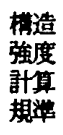 & $\begin{array}{l}\text { 昭5 } \\
\text { 建境 } \\
\text { 昭7 } \\
\text { 改正 }\end{array}$ & $\begin{array}{l}\mathrm{RC} \\
\text { 规笔 }\end{array}$ & $\begin{array}{l}\text { 多12年 } \\
\text { 踥 }\end{array}$ & $\begin{array}{l}\text { 物动 } \\
\text { 昭13 } \\
\text { 改正 }\end{array}$ & $\begin{array}{l}\text { 木造 } \\
\text { 小学 } \\
\text { 校設 } \\
\text { 計案 }\end{array}$ & $\begin{array}{l}2600 \text { 年 } \\
\text { 万博規 } \\
\text { 龩我 }\end{array}$ & $\begin{array}{l}\text { 建筑 } \\
\text { 而掽 } \\
\text { 權造 } \\
\text { 要項 }\end{array}$ & $\underset{\text { 案 }}{\mathrm{S} \text { 规席 }}$ & 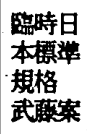 & 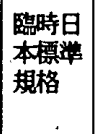 & $\begin{array}{l}\text { JES } \\
3001 \\
\text { 基桬法 } \\
\text { 施行令 }\end{array}$ \\
\hline 䅡 & \multicolumn{2}{|c|}{$\begin{array}{l}\text { 住宅 } \mathrm{kg} / \mathrm{m}^{2} \\
\text { 棸務所 } \mathrm{kg} / \mathrm{m}^{2} \\
\text { 数室 } \mathrm{kg} / \mathrm{m}^{2}\end{array}$} & $\begin{array}{l}83 \\
88 \\
88\end{array}$ & -1 & $\begin{array}{l}247 \\
370 \\
420\end{array}$ & $\begin{array}{l}250 \\
370 \\
420\end{array}$ & $\begin{array}{c}- \\
550 \\
-\end{array}$ & $\begin{array}{l}250 \\
370 \\
420\end{array}$ & $\begin{array}{l}- \\
- \\
-\end{array}$ & $\begin{array}{l}250 \\
370 \\
420\end{array}$ & $\begin{array}{l}250 \\
370 \\
420\end{array}$ & $\begin{array}{l}200 \\
300 \\
350\end{array}$ & $\begin{array}{l}200 \\
300 \\
350\end{array}$ & $\begin{array}{c}- \\
350\end{array}$ & $\begin{array}{l}\text { 令と } \\
\text { 涀㴖 } \\
\text { よる }\end{array}$ & $\begin{array}{l}- \\
- \\
-\end{array}$ & $\begin{array}{l}\text { 法令に } \\
\text { よる }\end{array}$ & けに & & 0 \\
\hline \multirow{3}{*}{$\begin{array}{l}\text { 非 } \\
\text { 常 } \\
\text { 時 } \\
\text { 荷 } \\
\text { 重 }\end{array}$} & \multicolumn{2}{|c|}{ 雪 単位 $\mathrm{kg} / \mathrm{m}^{2}$} & - & - & - & - & - & - & - & - & 3 & 3 & - & 3 & $\begin{array}{r}100 \mathrm{~kg} / \\
\mathrm{m}^{2}\end{array}$ & - & 3 & & & \\
\hline & \multicolumn{2}{|c|}{ 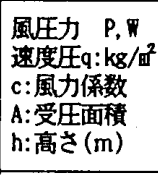 } & $\begin{array}{l}219 \\
\text { 煙突 } \\
244\end{array}$ & - & $\begin{array}{l}\text { 実況 } \\
\text { 煙突 } \\
198\end{array}$ & - & $\begin{array}{l}146 \\
(30 \\
1 \mathrm{~b} . / \\
\left.\mathrm{ft}^{2}\right)\end{array}$ & - & $\begin{array}{l}\text { 適当 } \\
\text { に } \\
\text { 仮定 }\end{array}$ & - & $\begin{array}{l}P= \\
i \\
15 \mathrm{~m} \\
100 \\
15 \\
150\end{array}$ & 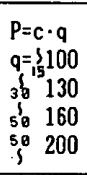 & - & $P=$ & 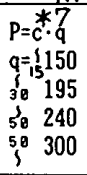 & - & 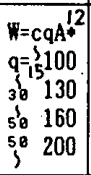 & 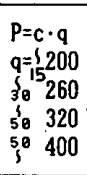 & $\begin{array}{ll}p=c \cdot q \\
q=40 \sqrt{h} \\
q=s & 80 \\
s^{\prime} & 140 \\
i^{\prime} & 140 \\
3 & 200\end{array}$ & 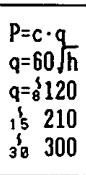 \\
\hline & \multicolumn{2}{|c|}{ 地震力 (震度) } & - & $0.3 * 3$ & - & - & $1 / 15$ & 0.1 & 0.1 & 0.1 & 0.1 & 0. & 0.1 & 0.1 & $.2 * 8$ & $0.3+9$ & $0.1 * 13$ & 0.3 & $0.15 \cdot 17$ & $0.2 * 19$ \\
\hline \multirow{4}{*}{$\begin{array}{l}\text { 許 } \\
\text { 容 } \\
\text { 応 } \\
\text { 力 } \\
\text { 度 } \\
+2\end{array}$} & \multirow{2}{*}{$\begin{array}{l}\text { コン } \\
\text { クリ } \\
\text { ート }\end{array}$} & $T$ & $\begin{array}{l}1.1 \\
-35.2\end{array}$ & - & 42.5 & 45 & - & $4 \dot{5}$ & - & F/3 & 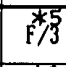 & $\mathrm{F} / 3^{\star 5}$ & $\mathrm{~F} / 3$ & $\cdot-$ & - & $\mathrm{F}$ & - & F/1.5 & F/1.5 & $\begin{array}{l}* 14 \\
7 / 1.5 \\
* 20\end{array}$ \\
\hline & & 引也㒋 & - & - & 4. 25 & 4. 5 & - & 4.5 & - & F/30 & $\mathrm{f} / 30$ & $F / 30^{* 6}$ & $\mathrm{~F} / 30$ & & - & *io & 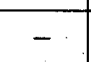 & $\mathrm{F} / 15^{75}$ & F/15 & $\begin{array}{r}7 \times 0 \\
F / 15 \div 20\end{array}$ \\
\hline & \multirow[t]{2}{*}{ 材 } & 圧引曲 & 1125 & - & 1125 & 1150 & - & 1150 & - & 1200 & 1200 & 1400 & 1400 & 1400 & 2800 & 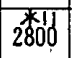 & $1600^{* 11}$ & 2400 & 2400 & $2400 * 21$ \\
\hline & & 七㒋 & 703 & - & 703 & 750 & - & 750 & - & 800 & - & 700 & 700 & $\div$ & 1400 & 1400 & $800^{k 11}$ & & 1200 & $1200+2$ \\
\hline
\end{tabular}

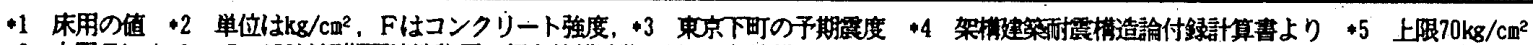

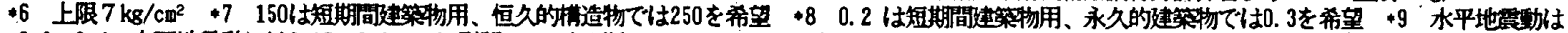

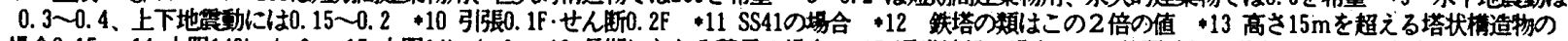

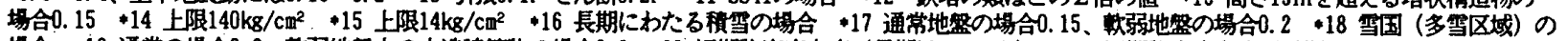

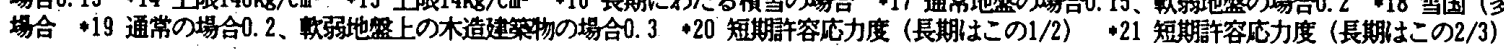

表一5 荷重 (応力) の組合せ (ここで, $G:$ 固定, $P:$ 積載, $S:$ 積雪, $W:$ 風, $K:$ 地震, $C:$ クレーン等の荷重 (による応力) を示す)

\begin{tabular}{|c|c|c|c|c|c|c|c|c|c|c|c|c|c|c|c|}
\hline $\begin{array}{l}\text { 法 } \\
\text { 命 } \\
\text { 等 }\end{array}$ & $\begin{array}{l}\text { 哧法 } \\
\text { 能行 } \\
\text { 瞡則 }\end{array}$ & $\begin{array}{l}\text { 日本 } \\
\text { 舆葥 } \\
\text { 行 }\end{array}$ & $\begin{array}{l}\text { 饬迲 } \\
\text { 大13 } \\
\text { 改正 }\end{array}$ & 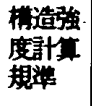 & $\begin{array}{l}\mathrm{RC} \\
\text { 规䈉 }\end{array}$ & $\begin{array}{l}\text { DIN1050 } \\
\text { 1934年 }\end{array}$ & $\begin{array}{l}\text { 物法昭 } \\
13 \text { 建請 } \\
\text { 改正 }\end{array}$ & $\begin{array}{l}\text { 木造小学 } \\
\text { 校楼钰 } \\
\text { 計菜 }\end{array}$ & $\begin{array}{l}\text { 同左武” } \\
\text { 清の怒想 }\end{array}$ & $\begin{array}{l}\text { 2600年 } \\
\text { 万博案 }\end{array}$ & $\begin{array}{l}\text { 建物 } \\
\text { 耐震櫵 } \\
\text { 造要項 }\end{array}$ & $\begin{array}{l}\text { S規灌 } \\
\text { 窭 }\end{array}$ & 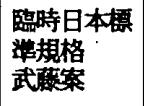 & 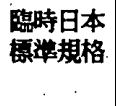 & 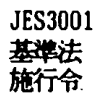 \\
\hline \multirow[t]{2}{*}{ 葆 } & $G, P$ & $\begin{array}{l}\text { G, P, } \\
\text { W, K }\end{array}$ & $\begin{array}{l}\text { G. P, } \\
K\end{array}$ & $\begin{array}{l}\text { G, P, K } \\
(\mathrm{W})\end{array}$ & $\begin{array}{l}\text { G, P, S, } \\
\mathbb{P}, \mathrm{K}\end{array}$ & $* 4$ & $\begin{array}{l}G, P, K \\
(S, W)\end{array}$ & $\begin{array}{l}\text { G, P, S; } \\
\text { W. K }\end{array}$ & $\begin{array}{l}\text { G, P, S } \\
\text { W, K, C }\end{array}$ & $\begin{array}{l}\text { G, P, S, } \\
W, K\end{array}$ & $\begin{array}{l}G, P, K \\
\text { に言及 }\end{array}$ & $\begin{array}{l}\text { G, P, S, } \\
\text { W. K }\end{array}$ & $\begin{array}{l}\text { G, P, S, } \\
\text { W, K, C }\end{array}$ & $\begin{array}{l}\text { G, P,S, } \\
\mathbb{W}, K\end{array}$ & $\begin{array}{l}G, P, S, \\
\mathbb{W}, K\end{array}$ \\
\hline & $\begin{array}{l}\text { 明示 } \\
\text { した } \\
\text { 规定 } \\
\text { なし }\end{array}$ & $\begin{array}{c}G+P \\
+K \\
G+P \\
+W \\
* 1\end{array}$ & $\begin{array}{l}\text { 明示 } \\
\text { した } \\
\text { 規定 } \\
\text { なし }\end{array}$ & $\begin{array}{l}G+P \\
G+P+K \\
G+P+W \\
* 2\end{array}$ & $\begin{array}{l}G+P \\
G+P+S \\
G+P+K \\
G+P+W \\
G+P+S \\
+K \\
G+P+S \\
+ \\
+W \\
* 3\end{array}$ & 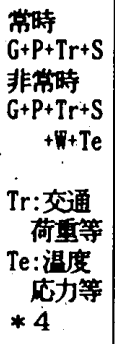 & $\begin{array}{l}\text { 明示し } \\
\text { た規定 } \\
\text { なし }\end{array}$ & $\begin{array}{l}G+P+S \\
G+P+W \\
G+W \\
G+0.5 P \\
+ \\
+\end{array}$ & 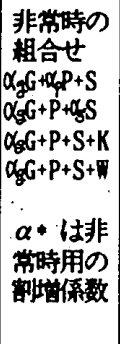 & $\begin{array}{l}2 G \\
2(G+P) \\
G+P+S \\
G+P+W \\
G+P+K \\
* 5\end{array}$ & $\begin{array}{l}G+P \\
G+P+K \\
\vdots \\
\eta リ- \\
7 \text { 考聕 } \\
2(G+P) \\
3(G+P) \\
* 6\end{array}$ & $\begin{array}{l}G+P \\
G+P+S \\
G+P+W \\
G+P+K \\
G+P+W \\
(+S) \\
G+P+K \\
(+S) \\
* 7\end{array}$ & $\begin{array}{l}\alpha(G+P)+C \\
\alpha(G+P)+C+T \\
G+W \\
\alpha(G+P)+C+K \\
G+K \\
\alpha(G+P)+C+S \\
\alpha=1.5(木 \\
\text { 及URC) } \\
\alpha=1.0 \\
G \text { は実呮の } \\
1.2 \text { 倍する }\end{array}$ & $\begin{array}{c}\text { 長期 } \\
G+P \\
\text { 木等 } \\
2(G+P) \\
\text { 短期 } \\
G+P+S \\
G+P+W \\
G+W \\
G+P+K \\
\text { 木等 } \\
2(G+P+S)\end{array}$ & $\begin{array}{c}\text { 長期 } \\
G+P \\
G+P+S \\
\text { 知期 } \\
G+P+S \\
G+P+W \\
G+P+K \\
G+P+W \\
(+S) \\
G+P+K \\
(+S)\end{array}$ \\
\hline
\end{tabular}

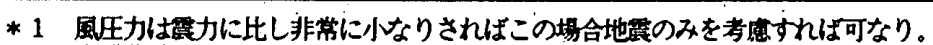

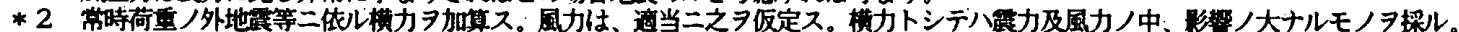

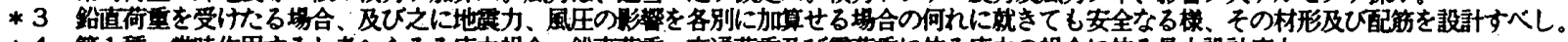

*4 第1種 常時作用すると考へらるる応力粗合 䛇直荷重、交通荷重及ひ雪何重に依る他力の粗合に依る权大設計応力

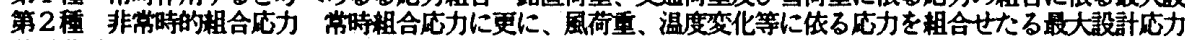

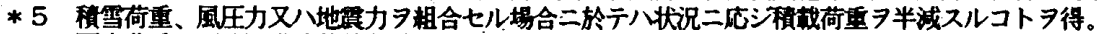

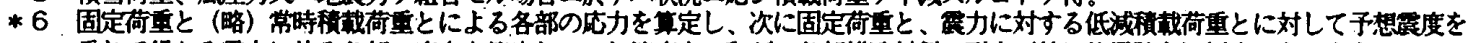

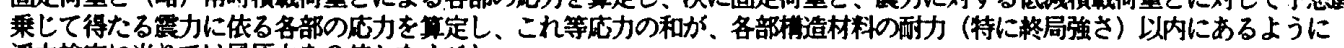

*7 浮力模定に当りては風在力を 2 倍となすべし。 
物法では, 荷重は固定荷重, 積載荷重が規定され, 他の 荷重は規定されず, 荷重の組合せ規定もなかったが, 物 法以前の設計にあるように, 必要に応じてこれらの鉛直 荷重と他の荷重との組合せは想定されていたと考える。

物法以前に震度法が提案され，風圧力案もあったが， 物法制定時には規定されなかった。その理由は, 地域差 が大きいことおよび水平力の応力計算法が未普及だった ことへの考慮と考える。

地震力は, 1923 年の関東大地震の翌年に物法に定め られた。同時期に制定された建築学会の構造強度計算規 準で, 実用的な水平力の応力計算法と荷重の組合せが定 められたが，これは荷重の組合せという新しい概念を導 入したのではなく，従来の手法を明示したものと考える。

風圧力は府県細則で定められた。材料安全率を考慮し て地震力と風圧力は小さく, 積載荷重には荷重側にも安 全率が含まれていた。1934 年の室戸台風の後, 棚橋らは, 部材の終局安全率の均一化之常時安全と地震安全の区分 の考えを提案した。DIN 規格での常時・非常時の概念 の導入もあり, 武藤らの検討を経て, 常時安全について は, クリープ考慮から長期間作用する荷重の応力割増に つながった。非常時安全については, 学術振興会の建築 物耐震構造要項などで, 終局強度型体系が検討され, 非 常時荷重之許容応力度が上昇した。この後に, 戦時規格 で, 常時安全確保はクリープ考慮の長期概念になり, 非 常時安全確保は短期概念になり，同時に，長期は常時作 用する荷重の組合せとし, 短期は常時の荷重に短期的荷 重の1つを加える，となった。戦後の JES 3001 でクリー プは応力の割増しではなく, 長期許容応力度が定められ, その值の低下で考慮するとされた。

ここで, 竹山が, JES 3001 の木造の長期はクリープ による変形増大防止が目的, 亡説明している点は注目で きる。木造の長期は破壊防止による安全性破保ではなく， 変形制限による機能性確保の観点がうかがえる。しかし, 木造以外では, クリープのない鋼材にも長期許容応力度 が定められ，長期の意味があいまいになった。筆者は， 竹山の指摘の上うに, 長期の計算は, 常時の荷重に対し, 常識的な部材断面を得るためとの解积が妥当と考える。

基準法の震度 0.2 は許容応力度の上昇に対応したもの で物法の震度 0.1 の延長であった。震度と短期許容応力 度は比較的多く発生する地震と弾性限度に対応するが, ここでも, 目標は, 1923 年の関東大地震程度の大地震 への安全確保であったと考える。1980 年の改正による 地震の標準せん断力係数 $C_{0}=0.2$ は震度 0.2 の延長で あるが, 現在の短期計算は, 層間変形角制限之連携して, 中地震時の建築物の機能性確保とされている ${ }^{62)}$ 。一方, 風圧力は, 当初, 許容応力度での安全率等を考慮して小 さな值であったが, 許容応力度の上昇によって, 過去の 最大值に相当するものとなった。風の短期計算の目標は,
地震のような機能性保持ではなく, 安全確保と洘えられ る。

筆者は, 荷重値等は変化したが, 規定の目標は, 物法 時代から基準法制定時まで一貫して大荷重への安全確保 であったと考える。少なくとも地震と風に対しては, 目 標は，大荷重に対する部材破壊防止による安全傕保であ り, 中規模の荷重に対する機能性確保の概念は薄く, 解 析手法を考慮して荷重と許容応力度は終局的なものより 小さい值が定められたもので, 基準法制定後に涀定の解 釈を変えて, 地震の短期計算は中規模地震に対する機能 性の保持，としたと考える。

長期は常時作用する荷重の組合せ, 短期は常時荷重に 短期的荷重を 1 つ組み合わせるという荷重組合せは, 物 法以前から考えられたが, 長期・短期概念の形成ととも に現在の形になった。なお，基準法は，荷重の組合せで はなく, 応力の組合せとしている。ここには荷重と荷重 効果との違いがあるが, 弾性解析では, 結果は同じであ ることおよび荷重と荷重効果の差を述べることは，本論 文の目的でないこと，からここでは「荷重組合せ」を用 いた。

こうした結果, 長期は材料により, 短期は荷重により, それぞれ計算の目標と意味に差が生じたと考える。この ような概念の不統一は好ましくなく，今後の構造計算法 は，その目標を明確化することが必要と考える。

\section{4. 結 論}

建築基淮法制定時の構造計算規定とその長期・短期概 念と荷重組合せの成立の過程を明らかにした。成立過程 と現在の問題点は次のようなものである。

1）当初, 物法は常時の荷重のみを規定し，1923 年の 関東大地震の後, 地震力規定を導入したが, 1934 年の 室戸台風後に棚橋の指摘, 武藤の検討などにより常時安 全と非常時安全の区分けがされて, 戦時規格をへて JESにより長期・短期概念にまとまった。基準法は JESによった。

2）長期は，木造のクリープ変形考慮が主だったが，鋼 材の長期の意味は不明確だった。短期は, 非常時の大荷 重への安全確保が目標だったが, 弹性解析を考慮してや や小さい值に決められた。ただし，地震と風では荷重の 水準の考え方に差があった。

3） 1980 年の改正で地震の短期計算は中規模地震での 機能性確保とされ，基準法制定時と，短期の意味に差が 生じ，風の短期計算の意味之も差が生じた。

4）常時荷重の組合せおよび常時荷重に短期的荷重を 1 つ加える荷重組合せの形は，基本は物法以前からあった が,長期・短期概念の形成とともに基準法の形になった。 5）今後, 概念の統一と規定の目標の明確化が必要であ る。 


\section{注および参考文献}

1）大橋雄二・橋川溶治：法令における構造関係規定の変遷 (その1) (その 2), 日本建築学会大会学術講演梗概集, 構造 I, pp. 1 4, 昭和 61 年 8 月, 同 (その 3 ) (その 4 ), 日本建築学会大会学術講演梗概集, 構造 I, pp. 1369 1372 , 昭和 62 年 10 月, 同（その 5 ）（その 6 ）（建築基 準法施行令の構造計算規定の制定の経緯（1）(2)), 日 本建築学会大会学術講演梗概集, 構造 I, pp. 1 4, 昭 和 63 年 10 月, 大橋雄二：我が国の建築法令における構 造強度規定の変遷, あらか, 建設省建築研究所編建築研 究成果撰第 5 集, pp. 1 28, 1987.10, 大橋雄二：荷重 関係法規の変遷, 日本建築学会設計荷重理論小委員会「設 計荷重の考え方」pp.49 61，1989.4，大橋雄二：構造 計算規定における長期・短期概念の成立に関する考察, 日本建築学会大会学術講演梗概集, 構造 I, pp. 135 136, 1990. 10 なよ゙

2）石川孝重・平田京子：東京市建築条例妻木案が果たした 役割, 日本建築学会構造系論文報告集, No. 397, pp. 32 ～41, 1989.3, 同著者：東京市建築条例学会案加市街 地建築物法施行規則に至る立案過程とその特徵，日本建 築学会構造系論文報告集, No. 406, pp. 12～23，1989.12, 同著者：東京市建築条例学会案加市街地建築物法施行 規則に至る構造計算にかかわる数値規定の変遷とその根 拠, 日本建築学会構造系論文報告集, No. 412, pp. 19 29, 1990.6

3）日本建築学会編：近代日本建築学発達史，丸善，.pp.981 ～993，1972. 10, 藤森照信: 明治の東京計画, 岩波書店, pp. 1 220, 1982. 11, 石田頼房 : 日本近代都市計画の百 年, 自治体研究社, pp. $32 \sim 44$, pp. $51 \sim 105,1987.1$ な ゼ

4）日本建築学会図書空妻木文庫による。研究資料は，石田 ·頼房：日本建築学会図書室所蔵妻木文庫中の建築法規関 係資料，総合都市研究，No. 19，pp. 169 188，1983.10， 片倉健雄：市区改正委員会による東京市建築条例諸案の 系譜, 日本都市計画学会学術研究論文集, 第 20 号, pp. $25 \sim 30$, 昭和 60 年 11 月, 加藤仁美：市区改正委員 会における東京市建築条例案の検討過程とその到達点, 日本建築学会計画系論文報告集, No. 376, pp. 95 105, 1987.6 など

5）日本建築学会図書室妻木文庫。注 4）の石田の文献にあ る

6) 日本建築学会図書室妻木文庫。伯林建築条例

7）神奈川県家作建方条目，明治 6 年 7 月 18 日，白石博三： 明治以後の建築法令, 建築関係法令の研究 11 , 日本建築 学会建築計画委員会建築規準小委員会, pp. 104 105, 昭和 57 年 9 月にある

8）斉藤和夫：明治 19 年制定長屋家屋建築令規の成立事情に ついて, 日本都市計画学会学術研究論文集, 第 17 号, pp. 403 408, 昭和 57 年 11 月

9）斉藤和夫，赤崎弘平：市街地建築物法制定以前における 建築規制関係地方令規の制定動向とその分布について， 日本建築学会近畿支部研究報告集, 第 22 号計画系, pp. 457 460, 昭和 57 年 6 月

10）日本建築学会編：近代日本建築学発達史, 丸善, pp:1 $49,1972.10$

11）日比忠彦：鉄骨構造建築学，建築雑誌，第 231 号，明治
39 年 3 月から, 传野利器: 建築構造強弱学, 建築雑誌, 第 219 号, 明治 38 年 3 月から, など

12）佐野利器：家屋酎震構造論, 震災予防調査会報告第 83 号, 大正 5 年（著者日付は大正 3 年 12 月）注 10）の文献 pp. 54〜61・に抄録がある。

13）佐野利器：風力に就て, 建築雑誌, 第 236 号, pp. 515 522 , 明治 39 年 8 月

14）東京市建築条例案起稿顛末報告, 建築雑誌, 第 323 号, pp. $558 \sim 565$ ，大正 2 年 11 月

15）建築学会東京市建築条例案は建築学会図書窒にある。注 7）の白石の文献 pp. 129 162 に成案がある。この制定 経過は注 2) の文献に詳しい。

16）中村達太郎：欧米建築条例の比較, 建築雑誌, 第 220 号, pp. 216 222, 明治 38 年 4 月

.17）建築取楴規則，大阪府合第 74 号，大阪府公報号外，明治 42 年 8 月 18 日, 注 7) の白石の文献 pp. 114 123

18）建築取締規則，兵庫県令第 2 号，兵庫県報第 1576 号，明 治 45 年 1 月 31 日，注 7）の白石の文献 pp. 124 128

19）内田祥三：市街地建築物法の回顧, 建築行政, 昭和 26 年 5 月号, pp. 2 8

20）鳘視厅建築取締規則草案（大正 7 年 8 月 30 日の日付）東 京都公文書館所蔵のものに基づいた。風圧力は第 111 条

21）内藤多仲：架構建築耐震構造論, 建築雑誌, 第 436 号, 大正 11 年 10 月より

22）内藤多仲: 架構建築耐震構造論 (六), 建築雑誌, 第 441 号, p. 81 ，大正 12 年 3 月

23）内藤多仲：架構建築耐震構造論（五）(六), 建築雑誌, 第 440 号, pp. $39 \sim 53$, 大正 12 年 2 月，同第 441 号， pp. $69 \sim 86$, 大正 12 年 3 月

24）注 10）の文献 pp. 1044～1062，注,3）の石田の文献 pp: $107 \sim 143$

25）都市計画法, 大正 8 年 4 月 4 日法律第 36 号, 市街地建築 物法, 大正 8 年 4 月 4 日法律第 37 号

26）市街地建築物法施行規則，大正 9 年 11 月 9 日内務省令第 37 号, 建築雑誌，第 408 号付録，pp. 1 5, 大正 9 年 11 月

27）伊藤憲太郎：積載荷重に就て, 建築雑誌, 第 628 号, pp. 858 863, “昭和 12 年 7 月

28）大正 13 年 6 月 12 日内務省令第 15 号，建築雑誌，第 456 号, pp. 464 466, 大正 13 年 7 月

29）北沢五郎：震度談，建築学大系 15 巻の月報，彰国社, 1957: 9，ここでは久田俊彦：地震と建築，鹿島出版会， pp. 49〜50，1974.9によった

30) 時局二関スル特別委員会 : 構造強度計算規準. (大正 13 年 12 月)，建築䧱誌，第 469 号巻末，pp. 1 - 5, 大正 14 年 4 月

31）市街地建築物法施行規則第 102 条（制定時）

32）浜田 稔：コンクリートの配合に関する研究, 建築雑誌, 第 520 号，pp. $325 \sim 346$, 昭和 4 年 4 月

33）村松貞次郎：日本近代建築技術史, 彰国社, pp. 154 159, 1976.9

34）建築法規改正に関する建議, 建築雑誌, 第 532 号, pp. $867 \sim 874$, 昭和 5 年 4 月

35）昭和 7 年 1 月 12 日内務省令第 1 号, 建築雑誌, 第 553 号, pp. 96 99, 昭和 7 年 1 月, 菱田厚介：市街地建築物法 の改正に就て, 建築雑誌, 第 554 号, pp. 267 276, 昭 
和 7 年 2 月

36）コンクリート及鉄筋コンクリート標準仕様書・鉄筋コン クリート構造計算規準, 建築学会, pp. $31 \sim 40$, 昭和 8 年 9 月

37）注 36）の文献 p. 75

38）警視庁令市街地建築物法施行細則第 27 条，昭和 3 年 11 月

39）山之内嘉兵衛：建築法令, 東学社, pp. 65 -67, 昭和 10 年 6 月, 伊藤憲太郎 - 伊藤鉀太郎：積載荷重の各国規定 其の他に関する資料, 建築雑誌, 第 646 号, pp. $25 \sim 37$, 昭和 14 年 1 月

40）建築法規改正に関する建議, 建築雑誌, 第 627 号, pp. 715 719, 昭和 12 年 6 月, 北沢五郎：市街地建築物 法施行規則中の荷重及許容応力度に関する条項の改正建 議に就て, 建築雑誌, 第 628 号, pp. $857 \sim 858$, 昭和 12 年 7 月

41）注 39）の伊藤らの文献

42）武藤 清: 鉄骨の許容応力度に就て, 建築雑誌, 第 628 号, pp. 866 869, 昭和 12 年 7 月

43）武藤 清：建築法規中鋼材の許容応力度の改正に就て, 日本建築学会論文報告集, 第 7 号, pp. 1 7, 昭和 12 年 12 月

44）森 徹：木材の許容応力度に就て, 建築雑誌, 第 628 号, pp. 864 866, 昭和 12 年 7 月, 森徹：建築用木材の 許容応力度に就て, 日本建築学会諭文報告集, 第 8 号, pp. 11 20, 昭和 13 年 2 月

45）昭和 12 年 6 月 12 日内務省令第 25 号, 建築雑誌, 第 628 号, 付録 p. 1, 昭和 12 年 7 月

46）木造規準調查委員会：木造 2 階建小学校校舎構造一案, 建築雑誌，第 635 号, pp. 113 136：昭和 13 年 2 月

47）棚橋 諒・宇津木潔: 耐震安全率の問題：日本建築学会 論文報告集, 第 1 号, pp. 177 180, 昭和 11 年 3 月
48）武藤 清：木造小学校標準教室構造設計に就ての感想, 建築雑誌，第 635 号, pp. 148 152, 昭和 13 年 2 月

49）武藤 清 - 長沼 重: 新形式の木構造計算法, 建築雑誌, 第 644 号, pp. 1191 1200, 昭和 13 年 11 月

50）日本学術振興会編：建築物耐震構造要項, 岩波曺店, pp. 18 29, 昭和 16 年 3 月

51）鉄骨構造計算規準 (案)，建築雑誌，第 681 号, pp. 941 $\sim 963$, 昭和 16 年 12 月

52）武藤 清：鉄骨構造計算規準（案）に就て，建築雑誌， 第 684 号, pp. 159 - 165, 昭和 17 年 3 月

53）竹山謙三郎：構造物の安全性と荷重及び許容応力度の取 扱ひに就いて, 建築雑誌, 第 699 号, pp. 464 -471, 昭 和 18 年 6 月

54）昭和 18 年 12 月 24 日栜令 942 号, 市街地建築物法戦時特 例

55）臨時日本標準規格第 532 号 - 第 533 号, 建築准誌, 第 $712 \cdot 713$ 号, pp. $281 \sim 288$, 昭和 19 年 $8 \cdot 9$ 月

56）石黒徳衛：建築構造の安全性と鋼材の許容応力度, 建築 技術，第 316 号, pp. 137 -145，1977. 12

57）学会情報, 建築雑誌, 第 $730 \cdot 731$ 号, p. 26, 昭和 22 年 $3 \cdot$ 4 月

58）日本建築規格建築 3001 , 建築雑誌, 第 $730 \cdot 731$, pp. 13 $\sim 25$, 昭和 22 年 $3 \cdot 4$ 月

59）竹山謙三郎：構造計算と建築物の安全性について, 建築 雑誌, 第 822 号, pp. 1 6, 昭和 30 年 5 月

60）昭和 25 年 5 月 24 日法律第 201 号

61）建築基準法解説, 日本建築学会, p. 3, p. 41, 昭和 25 年 11 月

62）構造計算指針・同解説 1988 年版, 日本建築センター, p. 105，1988. 5 など

(1990 年 9 月 1 日原稿受理, 1991 年 3 月 18 日採用決定） 